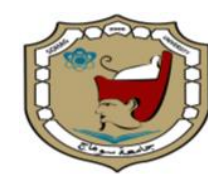

Sohag University

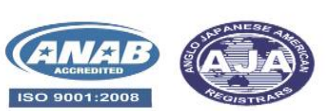

Sohag Medical Journal
Faculty of Medicine

\title{
Updates In The Pathogenesis Of Alopecia Areata
}

\author{
Essam El Din Abdel Aziz Nada, Hanan Abdel Radi Assaf, Suha \\ Heshmat Abu Al Dahab, Zainab Abu Al Baha Judeh
}

\author{
Department of Dermatology, Venereology and Andrology, Faculty of Medicine, \\ Sohag University.
}

\begin{abstract}
:
Alopecia areata is the most prevalent autoimmune disorder which causes non-scarring hair loss. It may increase the anxiety of patients and increase their chances of developing psychological and psychiatric disorders. There are two proposed theories for the pathogenesis of alopecia areata.

The most evidence-based hypothesis is an autoimmune reaction caused by the collapse of hair follicle immune privilege, Immune privilege collapse is assumed to be either a primary event that triggers antigen presentation in a disturbed hair follicle environment or an event that occurs as a result of dysregulation of the central immune system that involves the follicles.

Several gene loci have been identified with alopecia areata. The key immune effectors in the pathogenesis include autoreactive effector T cells, natural-killer group 2, member (NKG2D) + CD8+cytotoxic T cells, natural killer (NK) cells, Janus kinase, signal transducers, and activators of transcription (JAK/STAT) pathway, MHC-I chain-related gene A (MICA), interferon- $\gamma$ (IFN- $\gamma$ ) and interleukin-15 (IL-15).

Alopecia areata has no accepted cure and has an unpredictable response to treatment. The recognition of the exact pathogenic mechanisms of alopecia areata is necessary to identify the potential therapeutic targets.
\end{abstract}

Keywords: alopecia areata, pathogenesis, immune privilege.

\section{Introduction:}

Alopecia areata (AA) is a prevalent autoimmune skin disease that manifests as non-scarring patchy hair loss on the scalp and other hair-bearing areas. It has a general of $2 \%$ and has a lifetime risk of $1.7 \%{ }^{(1)}$. It has no age, sex, or ethnic predilection ${ }^{(2)}$.

Skin lesions of AA display peribulbar lymphocytic infiltration ${ }^{(3)}$, consisted of intra-follicular CD8+ $T$ cells and perifollicular CD4+ $\mathrm{T}$ forming "swarm of bees" ${ }^{4,5)}$, with elevated counts of telogen hairs in the acute and chronic stages, catagen hairs in the subacute stage and miniaturized hairs in the chronic stage (6).
The hair follicle (HF) immune privilege (IP):

The HF (IP) occurs during anagen. It's hypothesized to contribute to the de novo induction of peripheral tolerance, and is maintained through ${ }^{(7)}$ :

1-Downregulation of MHC I, MHC II (on antigen-presenting cells, APCs), and $\beta 2$-microglobulin expression. This inhibits IFN- $\gamma$ production by macrophages ${ }^{(8,9)}$.

2-Local immunosuppressants: transforming growth factor $\beta 1$ (TGF- $\beta 1$ ), IL$10, \alpha$-Melanocyte stimulating hormone ( $\alpha$-MSH), Indoleamine 2,3 dioxygenase (IDO), protein red encoded by IK gene (red/IK), insulin-like gro- 
SOHAG MEDICAL JOURNAL

Vol. 25 No. 2 April 2021

wth factor 1 (IGF-1), calcitonin gene-related peptide and somatostatin ${ }^{(8-}$ 12).

3-Extracellular matrix barriers that inhibit immune cell migration ${ }^{(8,9)}$.

4-Expression of Fas ligand and programmed cell death 1 ligand 1 (PD-L1) which target immune cells that penetrate the physical barriers ${ }^{(13,14)}$.

Normal human anagen HFs decrease the liability of interaction with NKG2D+ cells and suppress the NK cells via continuous downregulation of expression of NKG2D on local NK cells, and NKG2D ligands (MICA or UL16binding protein 3) on the keratinocytes, together with the secretion of macrophage migration inhibitory factor ${ }^{(15-17)}$.

\section{The theories that explain alopecia areata development: \\ 1- Immune privilege collapse:}

When the reactive oxygen species (ROS) can't be overcome effectively, it accumulates in HF keratinocytes and promotes MICA expression ${ }^{(15)}$. Upon MHC presentation, MICA+ cells become seen by NK cells through NKG2D receptors, activating the innate immunity $(15,18)$. MHC-I presentation exposes the secured antigens to the immune cells $(9,15,19,20)$.

Initially, HFs enter an anagen phase without the IP. The APCs recognize and present self-antigens via increased $\mathrm{MH}$ C I and II expression, too naïve T cells, which proliferate and differentiate into effector cells ${ }^{(5)}$.

Autoreactive lymphocytes, especially CD8+ cells and NKG2D+ cells, travel toward the HFs, destruct the anagen HFs and induce premature catagen (21) through Fas-FasL, perforin-granzyme pathways, IFN- $\gamma$, and IL-15. Antigen presentation activates CD4+ cells, especially $\mathrm{T}$ helper 1 (Th 1) subtypes, which secrete TNF- $\alpha$, IFN- $\gamma$, and IL-2 (5). Zeinab Abu-EI baha Gouda

Lymphocytic recruitment can induce the onset of AA, while the IFN- $\gamma$ positive feedback cycle can explain its chronicity and progressiveness ${ }^{(22)}$.

The infiltration of the anagen hair bulb by lymphocytes, dendritic cells, and NK cells $^{(4)}$, the lower levels of IP maintaining factors such as IDO, red/IK, TGF- $\beta$, and $\alpha-\mathrm{MSH}$ in lesional or perilesional alopecic skin ${ }^{(11,23)}$, the strong positive MICA expression by HF cells ${ }^{(15)}$, as well as the upregulated IFN- $\gamma$, chemokines (CXCLs) and intercellular adhesion molecules (ICAM2 and ICAM3) in AA lesions, prove the IP collapse $^{(23)}$.

\section{2- The hair follicle as a target of an impaired immune system:}

According to the second theory of AA, the initial step is the activation of immune cells, which then invade HFs and promote MHC and MICA expression through IFN- $\gamma$, resulting in IP collapse in the HFs ${ }^{24)}$.

Evidence supporting this theory is based on several experimental studies. The induction of AA just by transferring immune cells from AA affected mice like CD8+ cells, CD8+ NKG2D+ $\mathrm{T}$ cells, and cells co-cultured with IL15 , which upregulates NKG2D receptors ${ }^{(24-26)}$. The CD8+ NKG2D+T cells depleted lymph node cells are unable to induce $\mathrm{AA}^{(27)}$.

Mice with severe combined immune deficiency develop AA after exposure to IL2 rich peripheral blood mononuclear cell (PBMC) cultures from healthy populations. High doses of IL2 enhance the expression of NKG2D+ CD56+ cells ${ }^{(15,28)}$.

The autoimmune regulator (AIRE) gene mutation, inducing autoimmune polyendocrinopathy, candidiasis, and ectodermal dystrophy (APECED), in which AA is present in $40 \%$ of patients, supports this hypothesis ${ }^{(29)}$. AIRE gene 
polymorphisms were detected with non-APECED AA ${ }^{(30)}$.

The first cytokines released around HFs are IFN- $\gamma$ and TNF- $\alpha$. IFN- $\gamma$ stimulates the expression of MHC-I, MHC-II, NKG2D, and chemokines (CXCL9, CXCL10, CXCL11), which continuo-

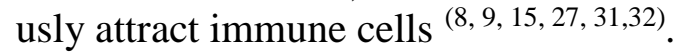
CXCL10, CCL3, and CCL5 were highly expressed, with chemokine receptor (CXCR3) $+\mathrm{T}$ cells around the HFs in $\mathrm{AA}^{(33)}$.

IL-2 and IL-15 and their receptors on CD8+ T cells are abundant around HFs (22, 34). IL-15 restricts the T reg cells' suppressive ability ${ }^{(35)}$, activates JAK, transforms CD8+ T cells to a cytotoxic phenotype ${ }^{(36)}$, and promotes NKG2D expression on NK cells transforming them into effector cells ${ }^{(37)}$.

Candidate genes for $\mathrm{AA}$ :

* Human leucocyte antigens; HLADRB1* 1104 and DQB1* 03 loci ${ }^{(38)}$. * NKG2D gene and its ligands, UL16-binding proteins (ULBP3), MICA, and retinoic acid early transcript 1L protein $($ RAET1L= ULBP6) (16).

* The genes of protein tyrosine phosphatase N22 (PTPN22), cytotoxic T lymphocyte-associated protein 4 (CTLA-4), IL2 receptor subunit alpha (IL2RA) ${ }^{(39)}$, IL-2/IL21 locus, and IKZF4 (Ikaros family zinc finger 4) ${ }^{(16)}$.

* Duplications in melanin-concentrating hormone $(\mathrm{MCH})$ receptor 2; MCHR2 and MCHR2 antisense RNA1, implicated in $\mathrm{MCH}$ signaling (40).

* Peroxiredoxin-5 (PRDX5) gene, its dysregulation allows survival of impaired cells (affected by ROS), and self-antigen and presentation ${ }^{(41)}$.

* The autoimmune regulator (AIRE) gene $^{(30)}$.

* Syntaxin-17 (STX17) gene, its protein has a role in melanogenesis ${ }^{(42)}$.

\section{Epigenetics and alopecia are- ata:}

Epigenetic mechanisms, such as increased methylation of genomic DNA and histone acetylation were found in PBMCs of AA patients ${ }^{(43,44)}$.

\section{Targeted antigens in alopecia areata:}

Melanogenesis-associated antigens ${ }^{(45)}$, trichohyalin, and keratin 16 are possible targets for T cells ${ }^{(46)}$ and autoantibodies (47)

Immune cells implicated in the pathogenesis of $\mathrm{AA}$ :

1- CD8+NKG2D+ T cells:

The dominant effectors infiltrating the HFs are CD8+NKG2D+T cells. CXCR3+CD8+T cells invade the HF in AA lesions, with upregulated CXCR3 ligands (CXCL9, CXCL10, CXCL11) ${ }^{(32)}$. Th17 cells around the HFs can play a role in AA ${ }^{(48)}$. Invariant NK cells, classic NK cells, type 1 innate lymphoid, cells, and gamma delta $\mathrm{T}$ cells produce IFN- $\gamma$ (49)

2- T Helper 2 (Th2) CD4+T cells:

In AA lesions, the counts of Th2 cells ${ }^{(50)}$, their cytokines (IL-23 and IL-

9) ${ }^{(34)}$, and their serum markers of the immune response (IL-4, IL-5, IL-6, IgE, CCL17, IL-13, IL-31, CCL13, CCL22, and CCL26) are increased (51), this may explain the association between atopic dermatitis and AA (52).

\section{3- Mast Cells (MCs):}

The numbers, proliferation, and degranulation of perifollicular MCs were increased with significantly more physical MCs and CD8+T cell contact in human AA skin compared to non- AA control skin. MCs may present autoantigens to $\mathrm{CD} 8+\mathrm{T}$ cells and/or costimulatory signals ${ }^{(53)}$. 
4- Plasmacytoid dendritic cells (PDCs):

The PDCs represent a connection between innate and adaptive immunity. They were identified infiltrating around HFs of AA ${ }^{(54)}$. Activated PDCs secrete large amounts of (IFN- $\alpha / \beta)$, which triggers $\mathrm{CD} 4+$ cells, CD8+ cells, and NK cells responses towards the HFs ${ }^{(55,56)}$.

\section{5- T- regulatory cells (Treg cells):}

The numbers of Treg cells were significantly lower in AA skin compared to controls and other skin diseases. They preserve peripheral tolerance by suppressing auto-reactive $\mathrm{T}$ cells ${ }^{(57)}$. Immune tolerance collapse and $T$ cell-mediated autoimmunity may be induced by Treg cell deficiency ${ }^{(58)}$.

\section{Cytokines and alopecia areata:}

TNF- $\alpha$, IFN- $\gamma$, and IL- $1 \mathrm{a} / \mathrm{IL}-1 \mathrm{~b}$ had aberrant expression in AA lesions (59) and peripheral blood ${ }^{(60)}$. The serum level of IL-15 was elevated in AA patients ${ }^{(61)}$. The Th1 markers (CXCL10, CCL3, CCL2) were increased in longlasting AA ${ }^{(50)}$. CCL17 serum level correlated with AA severity ${ }^{(62)}$.

IL-17, IL-22 in AA lesions, and IL-1, IL-17, TNF- $\alpha$, and TGF- $\beta$ in the serum, were significantly higher in AA patients than in controls. Lesional and serum IL17 levels positively correlated with the severity of AA ${ }^{(63)}$.

TNF- $\alpha$ has an anti-proliferative effect on the keratinocytes. It disturbs the hair cycle and induces catagen in ex vivo HFs ${ }^{(64)}$. TNF- $\alpha$ blockers induce AA ${ }^{(65)}$ by allowing uncontrolled secretion of IFN- $\gamma$ by PDCs ${ }^{(54)}$.

\begin{tabular}{lll} 
Molecular profile in chronic, & recurrent, and severe \\
\hline reculopecia
\end{tabular}
areata:

Long-lasting AA is associated with increased Th1 markers (CXCL10, CCL3, CCL2) ${ }^{(50)}$. The severity of AA positively correlated with serum levels of CCL17 and IL-17, as well as lesional IL-17 levels ${ }^{(62,36)}$.

\section{Toll-like receptors (TLRs) in alopecia areata:}

Intracellular TLRs 3,7,8,9 were significantly up-regulated with increased expression of their mRNA in PBMCs, lesional, and peri-lesional HF bulbs of patients with AA (66). Polymorphisms of TLR1 may be associated with AA susceptibility ${ }^{(67)}$.

\section{Immune checkpoints:}

Immune checkpoints negatively regulate the immune response to avoid prevent autoimmunity. They include CTLA4, PD-1 receptors, and PD-L1. CTLA-4 is an inhibitory receptor essentially expressed by Treg cells. It binds to B7 co-stimulatory molecules on APCs preventing $\mathrm{CD} 28$ costimulatory induced activation of effector T cells ${ }^{(68)}$.

PD-1 is an inhibitory receptor, which on binding to PD-L1 create a strong inhibitory signal, which suppresses pro-inflammatory $\mathrm{T}$ cell activation and maintains self-tolerance ${ }^{(68)}$. PD-1 inhibitors block T-cell inactivation and facilitate the T-cell invasion of the hair bulbar area inducing $\mathrm{AA}^{(69)}$.

\section{Oxidative Stress (OS):}

Exposure to ROS induces catagen and hair growth retardation in cultured HFs (70). Values of OS index (OSI), serum total oxidant capacity (TOC), and malondialdehyde (MDA) were significantly higher in AA cases than in controls. Serum total antioxidant capacity (TAC) was significantly lower in AA patients than in controls, with significantly higher MDA, TOC, and OSI and significantly lower TAC values in severe $\mathrm{AA}^{(19)}$.

The JAK/STAT pathway and alopecia areata: 
The JAK/STAT signaling is suppressed in the HFs during anagen ${ }^{(71)}$, as it can inhibit hair stem cell proliferation and activation ${ }^{(72)}$, and reduce angiogenesis (73). IFN- $\gamma$ and IL-15 are JAK/STAT pathway-dependent ${ }^{(74)}$.

Through JAK signaling, CD8+NKG2D+T cells are believed to mediate $\mathrm{AA}^{(75)}$. JAK3 was strongly expressed in skin lesions of AA ${ }^{(76)}$. The JAK activetion has been recognized by the existence of phosphorylated STAT proteins in HFs of AA, but not in normal HFs ${ }^{(27)}$.

\section{Vitamin D and alopecia areata:}

Vitamin D suppresses IFN- $\gamma$ secretion by in vitro activated human PBMCs and CD4+ T cells ${ }^{(77)}$, CD8+ T cells, CD4+ $\mathrm{T}$ cells proliferation, and the JAK/STAT pathway. It down-regulates the abnormally up-regulated intracellular TLRs, interferes with the interaction between MCs and CD8+ T cells, maintains MCs stability, enhances Treg cells function, and up-regulates PD-1/PDL1 , all of which help maintain IP ${ }^{(78)}$.

Vitamin D intake significantly increased serum levels of TAC and glutathione and decreased MDA concentration compared to placebo ${ }^{(79)}$.

\section{Psychological stress as a trigger of alopecia areata:}

In response to acute emotional stress, the receptors of corticotropin and corticotropin-releasing hormone $(\mathrm{CRH})$ are upregulated in AA lesions ${ }^{(83)}$, also, acetylcholine is upregulated, which can modulate the immune cells and upregulate TNF- $\alpha$, IFN- $\gamma$ and IL- 6 production ${ }^{(80)}$.

There are anatomical anomalies of the nerves supplying AA-affected HFs ${ }^{(81)}$. Substance P, CRH, and nerve growth factor (NGF) provoke degranulation of MCs with the secretion of histamine, TNF- $\alpha$, IL-6, and IL-1. Substance P promotes the ectopic expression of MHCI on the anagen HFs and upregulates
NGF, MHC-I, and 32 -microglobulin in ex vivo HFs leading to premature catagen induction and IP collapse ${ }^{(82)}$.

\section{Microbiota and diet relation to alopecia areata:}

The gut bacteria may contribute to the modulation of the onset of $\mathrm{AA}^{(83)}$. The diet has a geographical effect on the lifetime risk of acquiring AA. In the United States of America, the lifetime risk of AA is estimated to be around $1.7 \%$ as most of the population adhere to a western diet, whereas, in Japan, where persons adhere to soya-based eastern diets, the lifetime risk is no higher than $1 \%$. A soy-rich diet can delay AA onset or decrease its susceptibility ${ }^{(84)}$.

\section{Environmental factors linked to alopecia areata:}

The connection between Helicobacter pylori (H. pylori) and AA is debatable. Infection with $\mathrm{H}$. pylori triggers $\mathrm{AA}$ by stimulating Th1 and Th17 cell response and IFN- $\gamma$ secretion which ${ }^{(85)}$. Alopecia areata was induced by swine flu virus infection ${ }^{(86)}$, infectious mononucleosis ${ }^{(87)}$, and shortly after vaccinations against hepatitis B virus ${ }^{(88)}$, herpes zoster virus (89), Japanese encephalitis (90), clostridium tetani (91), and human papillomavirus ${ }^{(92)}$.

Interestingly, new cases of AA includeing alopecia totalis and Universalis, as well as, relapse of previous AA lesions were reported with COVID-19 infection, which may be related to the inflammatory storm of COVID-19 infection, and the psychological stress of the quarantine ${ }^{(93,94)}$. The low serum levels of zinc and selenium are confirmed risk factors for $\mathrm{AA}^{(94)}$.

\section{Conclusions:}

The collapse of IP, MHC presentation, IFN triggering of IP collapse, and disruption of the JAK/STST pathway are all essential and evidence-based pathogenic mechanisms of alopecia areata. 
CD8+NKG2D+T cells are the most important effectors in the immune response to AA. Oxidative stress, infections, and psychologic stress are all risk factors for AA induction

\section{Abbreviations:}

AA: Alopecia areata

AIRE: Autoimmune regulator APCs: Antigen-presenting cells APECED: Autoimmune polyendocrinopathy, candidiasis, and ectodermal dystrophy

$\mathrm{CD}$ : Cluster of differentiation

COVID-19: Coronavirus Disease-2019

$\mathrm{CRH}$ : Corticotropin-releasing hormone CTLA-4: Cytotoxic T lymphocyteassociated protein 4

CXCL: Chemokine

HF: Hair follicle

HLA: Human leukocyte antigen

H. pylori: Helicobacter pylori

ICAM: intercellular adhesion molecules

IDO: Indoleamine 2,3 dioxygenase

IFN- $\gamma$ : Interferon-gamma

IgE: Immunoglobulin $\mathrm{E}$

IGF-1: Insulin-like growth factor 1

IL: interleukin

IP: Immune privilege

JAK: Janus kinase

JAK/STAT: Janus kinase, and signal transducers and activators of transcription

MCH: melanin-concentrating hormone

MCs: Mast Cells

MDA: Malondialdehyde

MHC: Major histocompatibility antigen class

MICA: MHC class I chain-related A

$\alpha-\mathrm{MSH}: \quad$ Melanocyte stimulating

hormone

NGF: Nerve growth factor

NK: Natural-killer

NKG2D: Natural-killer group 2, member

OS: Oxidative Stress

OSI: Oxidative stress index

PDCs: Plasmacytoid dendritic cells
PD-L1: Programmed cell death 1 ligand 1

PBMC: Peripheral blood mononuclear cell

PTPN22: Protein tyrosine phosphatase N22

RAET1L: Retinoic acid early transcript 1L protein

ROS: Reactive oxygen species

TAC: Total antioxidant capacity

TOC: serum total oxidant capacity

STX17: Syntaxin-17

TGF- $\beta 1$ : Transforming growth factor $\beta 1$

TLRs: Toll-like receptors

TNF- $\alpha$ : Tumor necrosis factor-alpha

ULBP3: UL16-binding proteins

\section{References:}

1-Pratt C, King L Jr, Messenger A, Christiano A, Sundberg J: Alopecia areata. Nat Rev Dis Primers. 2017;3:17011.

2-Strazzulla L, Wang E, Avila L, Lo Sicco K, Brinster N, Christiano A, Shapiro J: Alopecia areata: Disease characteristics, clinical evaluation, and new perspectives on pathogenesis. J Am Acad Dermatol. 2018;78(1):1-12.

3- Tosti A, Whiting D, Iorizzo M, Pazzaglia M, Misciali C, Vincenzi C, Micali G: The role of scalp dermoscopy in the diagnosis of alopecia areata incognita. $\mathbf{J}$ Am Acad Dermatol. 2008 Jul;59(1):6467.

4-Mounsey A and Reed S. Diagnosing and treating hair loss. Am Fam Physician. 2009;80:356-62.

5-Guo H, Cheng Y, Shapiro J, McElwee K: The role of lymphocytes in the development and treatment of alopecia areata. Expert Rev Clin Immunol. 2015;11(12):1335-1351.

6-Ahmed Z, Banik R, Paul H, Jaigirdar Q, Begum F, Chowdhury S: Histopathological changes in different stages of alopecia areata. Mymensingh Med J. 2010;19(1):100-105.

7-Paus R, Bulfone-Paus S, Bertolini M: Hair follicle immune privilege revisited: the key to alopecia areata management. 
J Investig Dermatol Symp Proc. 2018;19(1): S12-S17.

8-Ito T, Ito N, Bettermann A, Tokura Y, Takigawa M, Paus R: Collapse and restoration of MHC class-I-dependent immune privilege: exploiting the human hair follicle as a model. Am J Pathol. 2004;164(2): 623-634.

9-Gilhar A: Collapse of immune privilege in alopecia areata: coincidental or substantial? J Invest Dermatol. 2010;130(11):2535-2537.

10- Kinori M, Bertolini M, Funk W, Samuel L, Meyer K, Emelianov V, Hasse S, Paus R: Calcitonin generelated peptide (CGRP) may award relative protection from the interferon$\gamma$-induced collapse of human hair follicle immune privilege. Exp Dermatol. 2012;21(3):223-226.

11- Kang H, Wu WY, Lo BK, Yu M, Leung G, Shapiro J, McElwee KJ: Hair follicles from alopecia areata patients exhibit alterations in immune privilegeassociated gene expression in advance of hair loss. J Invest Dermatol. 2010;130(11):2677-2680.

12-Breitkopf T, Lo B, Leung G, Wang E, Yu M, Carr N, Zloty D, Cowan B, et al: Somatostatin expression in human hair follicles and its potential role in immune privilege. J Invest Dermatol. 2013;133(7):1722-1730.

13-Ferguson TA and Griffith TS: A vision of cell death: Fas ligand and immune privilege 10 years later. Immunol Rev. 2006;213:228-38.

14-Wang X, Marr A, Breitkopf T, Leung G, Hao J, Wang E, Kwong N, Akhoundsadegh N, et al: Hair Follicle Mesenchyme-Associated PD-L1 Regulates T-Cell Activation Induced Apoptosis: A Potential Mechanism of Immune Privilege. J Invest Dermatol. 2014;134(3):736-745.

15-Ito T, Ito N, Saathoff M, Hashizume H, Fukamizu H, Nickoloff B, Takigawa M, Paus R: Maintenance of hair follicle immune privilege is linked to the prevention of NK cell attack. J Invest Dermatol. 2008;128(5): 1196-1206.

16- Petukhova L, Duvic M, Hordinsky M, Norris D, Price V, Shimomura Y, Kim
$\mathrm{H}$, Singh $\mathrm{P}$ et al: Genome-wide association study in alopecia areata implicates both innate and adaptive immunity. Nature. 2010;466(7302): 113-117.

17-Li J, van Vliet C, Rufaut N, Jones L, Sinclair R, Carbone F: Laser Capture Microdissection Reveals Transcriptional Abnormalities in Alopecia Areata before, during, and after Active Hair Loss. J Invest Dermatol. 2016; 136(3):715-718.

18- Islam N, Leung PS, Huntley AC, Gershwin ME. The autoimmune basis of alopecia areata: a comprehensive review. Autoimmun Rev. 2015; 14(2): 81-89.

19- Bakry OA, Elshazly RM, Shoeib MA, Gooda A. Oxidative stress in alopecia areata: a case-control study. Am J Clin Dermatol 2014;15:57-64.

20- Prie BE, Voiculescu VM, IonescuBozdog OB, Petrutescu B, Iosif L, Gaman LE, Clatici VG, Stoian I et al: Oxidative stress and alopecia areata. $\mathbf{J}$ Med Life 2015;8:43.

21-Gilhar A, Schrum AG, Etzioni A, Waldmann H, Paus R: Alopecia areata: Animal models illuminate autoimmune pathogenesis and novel immunotherapeutic strategies. Autoimmun Rev. 2016;15(7):726-735.

22- Freyschmidt-Paul P, McElwee K.J, Hoffmann R, Sundberg J.P, Vitacolonna M, Kissling S, Zöller M: Interferon- $\gamma$-deficient mice are resistant to the development of alopecia areata. Br J Dermatol 2006;155: 515-521.

23- Subramanya RD, Coda AB, Sinha AA: Transcriptional profiling in alopecia areata defines immune and cell cycle control related genes within diseasespecific signatures. Genomics 2010;96:146-53.

24- McElwee KJ, Freyschmidt-Paul P, Hoffmann R, Kissling S, Hummel S, Vitacolonna M, Zöller M. Transfer of CD8(+) cells induces localized hair loss whereas $\mathrm{CD} 4(+) / \mathrm{CD} 25(-)$ cells promote systemic alopecia areata and CD4(+)/CD25(+) cells blockade disease onset in the $\mathrm{C} 3 \mathrm{H} / \mathrm{HeJ}$ mouse 
SOHAG MEDICAL JOURNAL

Vol. 25 No. 2 April 2021

model. J Invest Dermatol. 2005;124(5):947-957.

25- Wang EHC, Khosravi-Maharlooei M, Jalili RB, Yu R, Ghahary A, Shapiro J, McElwee KJ: Transfer of Alopecia Areata to $\mathrm{C} 3 \mathrm{H} / \mathrm{HeJ}$ Mice Using Cultured Lymph Node-Derived Cells. J Invest Dermatol. 2015;135 (10):25302532.

26- Zhang C, Zhang J, Niu J, Zhang J, Tian Z: Interleukin-15 improves cytotoxicity of natural killer cells via up-regulating NKG2D and cytotoxic effector molecule expression as well as STAT1 and ERK1/2 phosphorylation. Cytokine. 2008;42(1):128-136.

27- Xing L, Dai Z, Jabbari A, Cerise JE, Higgins CA, Gong W, de Jong A, Harel $\mathrm{S}$ et al: Alopecia areata is driven by cytotoxic $\mathrm{T}$ lymphocytes and is reversed by JAK inhibition. Nat Med. 2014;20(9):1043-1049.

28- Gilhar A, Keren A, Shemer A, d'Ovidio R, Ullmann Y, Paus R: Autoimmune disease induction in a healthy human organ: a humanized mouse model of alopecia areata. J Invest Dermatol. 2013;133(3):844-847.

29- Collins SM, Dominguez M, Ilmarinen $\mathrm{T}$, Costigan $\mathrm{C}$, Irvine $\mathrm{AD}$ : Dermatological manifestations of autoimmune polyendocrinopathycandidiasis-ectodermal dystrophy syndrome. Br J Dermatol. 2006;154(6): 1088-93.

30-Wengraf D, McDonagh A, Lovewell T, Vasilopoulos Y: Genetic analysis of autoimmune regulator haplotypes in alopecia areata. Tissue Antigens. 2008;71:206-212.

31- McPhee CG, Duncan FJ, Silva KA, King LE Jr, Hogenesch H, Roopenian DC, Everts HB, Sundberg JP: Increased expression of $\mathrm{Cxcr} 3$ and its ligands, Cxc19, and Cxcl10, during the development of alopecia areata in the mouse. J Invest Dermatol 2012;132:1736.

32- Dai Z, Xing L, Cerise J, Wang EH, Jabbari A, de Jong A, Petukhova L, Christiano AM, et al: CXCR3 blockade inhibits $\mathrm{T}$ cell migration into the skin and prevents the development of
Updates In The Pathogenesis Of Alopecia Areata

Zeinab Abu-EI baha Gouda

alopecia areata. J Immunol. 2016;197:1089- 1099.

33- Ito $\mathrm{T}$, Hashizume $\mathrm{H}$, Shimauchi $\mathrm{T}$, Funakoshi A, Ito N, Fukamizu H, Takigawa M, Tokura Y: CXCL10 produced from hair follicles induces Th1 and Tc1 cell infiltration in the acute phase of alopecia areata followed by sustained Tc1 accumulation in the chronic phase. J Dermatol Sci. 2013;69: 140-147.

34-Fuentes-Duculan J, Gulati N, Bonifacio K, Kunjravia N, Zheng X, SuárezFariñas M, Shemer A, Guttman-Yassky $\mathrm{E}$ et al: Biomarkers of alopecia areata disease activity and response to corticosteroid treatment. Exp Dermatol. 2016;25(4):282-286.

35- Jabri B and Abadie V: IL-15 functions as a danger signal to regulate tissueresident $\mathrm{T}$ cells and tissue destruction. Nat Rev Immunol. 2015;15: 771-783.

36- Meresse B, Curran SA, Ciszewski C, Orbelyan G, Setty M, Bhagat G, Lee L, Tretiakova $\mathrm{M}$ et al: Reprogramming of CTLs into natural killer-like cells in celiac disease. J Exp Med. 2006;203:1343-1355.

37- Tang F, Sally B, Ciszewski C, Abadie V, Curran SA, Groh V, Fitzgerald O, Winchester RJ et al: Interleukin 15 primes natural killer cells to kill via NKG2D and cPLA2 and this pathway is active in psoriatic

arthritis. PLOS ONE. 2013;8 e76292.

38-Alkhalifah A, Alsantali A, Wang E, McElwee K, Shapiro J: Alopecia areata update: part I. Clinical picture, histopathology, and pathogenesis. J Am Acad Dermatol. 2010;62(2):177-188.

39-Moravvej H, Tabatabaei-Panah P, Abgoon R, Khaksar L, Sokhandan M, Tarshaei S, Ghaderian S, Ludwig R: Genetic variant association of PTPN22, CTLA4, IL2RA, as well as HLA frequencies in susceptibility to alopecia areata. Immunol Invest. 2018;47(7):666-679.

40-Fischer J, Degenhardt F, Hofmann A, Redler S, Basmanav F, HeilmannHeimbach S, Hanneken S, Giehl K et al: Genomewide analysis of copy number variants in alopecia areata in a Central 
SOHAG MEDICAL JOURNAL

Vol. 25 No. 2 April 2021
European cohort reveals association with MCHR2. Exp Dermatol. 2017;26(6):536-541.

41-Petukhova L, Cabral R, MackayWiggan J, Clynes R, Christiano A: The genetics of alopecia areata: what's new and how will it help our patients? Dermatol Ther. 2011;24(3):326-336.

42-Erjavec S, Abdelaziz A, Patel A, Petukhova L, Christiano A: Sudden whitening of the hair. Role of the autophagy protein, Syntaxin 17 (STX17), in melanogenesis and alopecia areata. J Invest Dermatol. 2018;138(5): S140.

43-Zhao M, Liang G, Wu X, Wang S, Zhang P, Su Y, Yin H, Tan Y: Abnormal epigenetic modifications in peripheral blood mononuclear cells from patients with alopecia areata. $\mathrm{Br} \mathrm{J}$ Dermatol. 2012;166(2):226-273.

44-Wang E, DeStefano G, Patel A, Drill E, Harel S, Cela C, Tavazoie M, Christiano A: Identification of differentially expressed miRNAs in alopecia areata that target immune-regulatory pathways. Genes Immun. 2017;18(2):100-104.

45-Finner A: Alopecia areata: Clinical presentation, diagnosis, and unusual cases. Dermatol Ther. 2011;24(3):348354.

46-Wang E, Yu M, Breitkopf T, Akhoundsadegh N, Wang X, Shi F, Leung G, Dutz J: Identification of Autoantigen Epitopes in Alopecia

Areata. J Invest Dermatol. 2016;136 (8):1617-1626.

47-Leung M, Sutton C, Fenton D, Tobin D: Trichohyalin is a potential major autoantigen in human alopecia areata. $\mathbf{J}$ Proteome Res. 2010;9(10): 5153-5163.

48-Hong J, Lee C, Ha S, Choi S, Kim T, Song K, Kim K: The Contributory Roles of Th17 Lymphocyte and Cytotoxic T Lymphocyte at the Hair Bulge Region as Well as the Hair Bulb Area in the Chronic Alopecia Areata Patients. Ann Dermatol. 2017;29(2):156-166.

49-Laufer Britva R, Keren A, Ullmann Y, Paus R, Gilhar A: Possible role of ILC1 in the pathogenesis of alopecia areata. $\mathrm{J}$ Invest Dermatol. 2019;139: S88.
50-Czarnowicki T, He H, Wen H, Hashim P, Nia J, Malik K, Estrada Y, Kimmel G: Alopecia areata is characterized by expansion of circulating Th2/Tc2/Th22, within the skin-homing and systemic Tcell populations. Allergy. 2018;73(3):713-723.

51-Attia E, El Shennawy, Safin A: Serum Interleukin-4 and Total Immunoglobulin $\mathrm{E}$ in Nonatopic Alopecia Areata Patients and HLADRB1 Typing. Dermatol Res Pract. 2010;2010:503587.

52-Barahmani N, Schabath M, Duvic M: National Alopecia Areata Registry. History of atopy or autoimmunity increases the risk of alopecia areata. $\mathbf{J}$ Am Acad Dermatol. 2009;61(4):581591.

53-Bertolini M, Zilio F, Rossi A, Kleditzsch P, Emelianov VE, Gilhar A, Keren A, Meyer KC: Abnormal interactions between perifollicular mast cells and CD8+ T-cells may contribute to the pathogenesis of alopecia areata. PLoS One. 2014;9(5):e94260.

54-Abou Rahal J, Kurban M, Kibbi A, Abbas O: Plasmacytoid dendritic cells in alopecia areata: missing link? J Eur Acad Dermatol Venereol. 2016; 30(1):119-123.

55-Charles J, Chaperot L, Salameire D, Di Domizio J, Aspord C, Gressin R, Jacob M, Richard M: Plasmacytoid dendritic cells and dermatological disorders: focus on their role in autoimmunity and cancer. Eur J Dermatol. 2010;20(1):1623.

56- Ghoreishi M, Martinka M, Dutz J: Type 1 interferon signature in the scalp lesions of alopecia areata. $\mathrm{Br} \mathbf{J}$ Dermatol. 2010;163(1):57-62.

57-Speiser J, Mondo D, Mehta V, Marcial S, Kini A, Hutchens K: Regulatory Tcells in alopecia areata. J Cutan Pathol. 2019;46(9):653-658.

58-Han Y, Sheng Y, Xu F, Qi S, Liu X, Hu R, Miao Y, Huang GQ, et al: Imbalance of T-helper 17 and regulatory $\mathrm{T}$ cells in patients with alopecia areata. J Dermatol. 2015;42(10):981-988.

59-Kuwano Y, Fujimoto M, Watanabe R, Ishiura N, Nakashima H, Ohno Y, Yano 
$\mathrm{S}$, Yazawa $\mathrm{N}$ et al: Serum chemokine profiles in patients with alopecia areata. Br J Dermatol. 2007;157(3):466-473.

60-Timbre $M$ and Sharma V: Helper and regulatory T-cell cytokines in the peripheral blood of patients with active alopecia areata. Br J Dermatol. 2013; 169(3):543-348.

61-Ebrahim A, Salem R, El Fallah A, Younis E: Serum interleukin-15 is a marker of alopecia areata severity. Int $\mathbf{J}$ Trichology. 2019;11(1):26-30.

62-Inui S, Noguchi F, Nakajima T, Itami S: Serum thymus and activation-regulated chemokine as disease activity and response biomarker in alopecia areata. $\mathbf{J}$ Dermatol. 2013;40(11):881-885.

63-Loh S, Moon H, Lew B, Sim W: Role of $\mathrm{T}$ helper 17 cells and $\mathrm{T}$ regulatory cells in alopecia areata: comparison of the lesion and serum cytokine between controls and patients. J Eur Acad Dermatol Venereol. 2018;32(6):10281033.

64-Kasumagic-Halilovic E, Cavaljuga S, Prohic A: Tumor necrosis factor-alpha in patients with alopecia areata. Indian J. Dermatol. 2011;56 (5):494-496.

65-Ribeiro L, Rego J, Estrada B, Bastos P, Piñeiro Maceira J, Sodré C: Alopecia secondary to anti-tumor necrosis factoralpha therapy. An Bras Dermatol. 2015;90(2):232-235.

66-Kang H, Wu W, Yu M, Shapiro J, McElwee K: Increased expression of TLR7 and TLR9 in alopecia areata. Exp Dermatol. 2020;29(3):254-258.

67-Seok H, Suh D, Jo B, Lee H, Jang H, Park H, Lew B, Chung J: Association between TLR1 polymorphisms and alopecia areata. Autoimmunity. 2014;47(6):372-377.

68-Miko E, Meggyes M, Doba K, Barakonyi A, Szereday L: Immune Checkpoint Molecules in Reproductive Immunology. Front Immunol. 2019; 10:846.

69-Guidry J, Brown M, Medina T: PD-1 inhibitor-induced alopecia areata. Dermatol Online J. 2018;24(12):13030.

70-Haslam I, Jadkauskaite L, Szabó I, Stage S, Hesebeck-Brinckmann J, Jenkins $G$, Bhogal R, Lim $F$ et al:
Oxidative damage control in a human (mini-) organ: Nrf2 activation protects against oxidative stress-induced hair growth inhibition. J Invest Dermatol. 2017;137(2):295-304.

71-Triyangkulsri $\mathrm{K}$ and Suchonwanit P: Role of Janus kinase inhibitors in the treatment of alopecia areata. Drug Des Devel Ther. 2018;12:2323-2335.

72-Harel S, Higgins C, Cerise J, Dai Z, Chen J, Clynes R, Christiano A: Pharmacologic inhibition of JAK-STAT signaling promotes hair growth. Sci Adv. 2015;1(9):e1500973.

73-Meephansan J, Thummakriengkrai J, Ponnikorn S, Yingmema W, Deenonpoe R, Suchonwanit P: Efficacy of topical tofacitinib in VEGF promoting hair growth in non-scarring alopecia: possible mechanism via induction. Arch Dermatol Res. 2017;309(9):729-738.

74-Crowley E, Fine S, Katipunan K, Gooderham M: The Use of Janus Kinase Inhibitors in Alopecia Areata: A Review of the Literature. J Cutan Med Surg. 2019;23(3):289-297.

75-Blume-Peytavi U and Vogt A: Translational Positioning of Janus Kinase (JAK) Inhibitors in Alopecia Areata. EBioMedicine. 2015;2(4):282283.

76-Alves de Medeiros A, Speeckaert R, Desmet E, Van Gele M, DeSchepper S, Lambert J: JAK3 as an Emerging Target for Topical Treatment of Inflammatory Skin Diseases. PLoS One. 2016;11(10): e0164080.

77-Ragab D, Soliman D, Samaha D, Yassin A: Vitamin D status and its modulatory effect on interferon-gamma and interleukin-10 production by peripheral blood mononuclear cells in culture. Cytokine. 2016;85:5-10.

78-Lin X, Meng X, Song Z: Vitamin D and alopecia areata: possible roles in pathogenesis and potential implications for therapy. Am $J$ Transl Res. 2019;11(9):5285-5300.

79-Sepidarkish M, Farsi F, AkbariFakhrabadi M, Namazi N, AlmasiHashiani A, Maleki Hagiagha A, Heshmati J: The effect of vitamin D supplementation on oxidative stress 
parameters: A systematic review and meta-analysis of clinical trials. Pharmacol Res. 2019;139:141-152.

80-Alexopoulos A and Chrousos G: Stressrelated skin disorders. Rev Endocr Metab Disord. 2016;17(3):295-304.

81-Fujii T, Mashimo M, Moriwaki Y, Misawa H, Ono S, Horiguchi $\mathrm{K}$, Kawashima K: Physiological functions of the cholinergic system in immune cells. J Pharmacol Sci. 2017;134(1):121.

82-Peters E, Liotiri S, Bodó E, Hagen E, Bíró T, Arck P, Paus R: Probing the effects of stress mediators on the human hair follicle: substance $\mathrm{P}$ holds a central position. Am J Pathol. 2007;171(6):1872-1886.

83-Machado M and Cortez-Pinto H: Diet, Microbiota, Obesity, and NAFLD: A Dangerous Quartet. Int $\mathrm{J}$ Mol Sci. 2016;17(4):481.

84-McElwee K, Niiyama S, FreyschmidtPaul P, Wenzel E, Kissling S, Sundberg J, Hoffmann R: Dietary soy oil content and soy-derived phytoestrogen genistein increase resistance to alopecia areata onset in $\mathrm{C} 3 \mathrm{H} / \mathrm{HeJ}$ mice. Exp Dermatol. 2003;12(1):30-36.

85-Larussa T, Leone I, Suraci E, Imeneo M, Luzza F: Helicobacter pylori and $\mathrm{T}$ Helper cells: mechanisms of immune escape and tolerance. J. Immunol. Res. 2015;2015(12):1-10.

86-Ito $\mathrm{T}$ and Tokura Y: Alopecia areata triggered or exacerbated by swine flu virus infection. J Dermatol. 2012;39(10):863-864.

87-Rodriguez T and Duvic M: Onset of alopecia areata after Epstein-Barr virus infectious mononucleosis. J Am Acad Dermatol. 2008;59(1):137-

139.

88-Wise R, Kiminyo K, Salive M: Hair loss after routine immunizations. J Am Med Assoc. 1997;278(14):1176-1178.

89-Lai Y and Yew Y: Severe Autoimmune Adverse Events Post Herpes Zoster Vaccine: A Case-Control Study of Adverse Events in a National Database. J Drugs Dermatol. 2015;14(7):681-684.

90-Chu C, Cheng Y, Chan J: Alopecia areata after vaccination: recurrence with rechallenge. Pediatr. Dermatol. 2016;33(3):e218-e219.

91-Sánchez-Ramón S, Gil J, CianchettaSívori M, Fernández-Cruz E: Alopecia universalis in an adult after routine tetanus toxoid vaccine. Med Clin (Barc). 2011;136:318.

92-Geier D and Geier M: A case-control study of quadrivalent human papillomavirus vaccine-associated autoimmune adverse events. Clin Rheumatol. 2015;34(7):1225-1231.

93-FIvenson D: COVID-19: association with rapidly progressive forms of alopecia areata. Int $\mathbf{J}$ Dermatol. 2020;60(1):127.

94-Rinaldi F, Trink A, Giuliani G, Pinto D. Italian Survey for the Evaluation of the Effects of Coronavirus Disease 2019 (COVID-19) Pandemic on Alopecia Areata Recurrence. Dermatol Ther. 2021;1-7.

95-Jin W, Zheng H, Shan B, Wu Y: Changes of serum trace elements level in patients with alopecia areata: a metaanalysis. J Dermatol. 2017; 44:588-591. 